"While in many respects the technical coverage pertains to pine throughout its whole range, the emphasis is on pine in Canada, and particularly in the Great Lakes - St. Lawrence Forest Region where pine production is most important today.

"In Canada white and red pine have almost identical ranges, occupy to a large extent similar sites, occur frequently in mixture, and are both of considerable economic interest; therefore it is expedient to deal with them in combination. This, then, is both a monograph of the white and red pine forest type and a comparative study of the two species.

"It is almost wholly a literature review."

The bulletin is well documented and contains so much material as to be a valuable source of reference for all those foresters who are lucky enough to be practicing in the white and red pine producing areas. It covers such topics of importance as: silvics, comparative autecology, synecology, artificial reproduction, stand improvement, harvest cutting and reproduction methods, growth and yield, entomology, pathology and research requirements. Specialists in most fields will find up-to-date references covering the subjects concerned.

Silviculture of white and red pine in the near future and even today, in many parts of Canada, will be mainly in plantations and other young growing stands. Foresters' viewpoints will change rapidly and many of the historical conclusions based on operations in overmature pine will become less valid. In cleaning, thinning and stand improvement practices we shall find that pine is amenable to treatment; that growth may be phenomenal in comparison with old standards and that regeneration of the crop will come as one of the normal steps in pine management. Weevil and ribes control will be integrated with other treatments.

This bulletin can supply much of the basic text for reference and guidance to the pine manager of the future. It should not be forgotten, however, that the economic aspects will generally govern the application of various practices.

The authors stated that: "There is a wealth of information on white and red pine"-and also suggested that: "still there remains a multitude of problems requiring research of various intensity. The relative urgency of these problems is largely a matter of viewpoint."-This is a most objective approach toward research. Not many foresters can give an unbiased opinion as to the need for further research. We seem to know a great deal more about what constitutes good practice, than what the present economic conditions will permit. There is a constant struggle to get funds for demonstration purposes and for investment in silviculture. This struggle is quite often in competition with demands for further research funds.

M. B. MORISON

\title{
Abstracts of U.N.B. M.F. Theses
}

Hanusiak, R. E. Development of Decay and Utilization Factors for the Tuadook Lake Area of New Brunswick. 1961.

In 1959 a study was conducted in the Tuadook Lake area of New Brunswick for the purpose of establishing decay and utilization-reduction factors for stands of softwood trees. These factors serve a two-fold purpose: first to estimate net merchantable volume from gross measured volume, and secondly to remove from individual cruisers the responsibility of making diameter reductions for apparent physical defect during inventory cruises. 
All softwood trees, merchantable for pulpwood, on 55 square, tenthacre, randomly selected plots were sectioned and measured. Tree volumes and decay volumes were compiled by Smalian's formula. The decay volume was expressed as a ratio of gross merchantable volume for each tree and as a total for each stand. Compilation also showed the relationship between volume of decay and diameter breast height, age and number of trees.

Four per cent of the total gross merchantable volume of wood is decayed and has no present commercial value. The loss of wood volume, through decay, varies from two per cent in white and red spruce to six per cent in balsam fir. Much of the decay volume is in the advanced stage.

Loach, A. M. An Investigation of the Distribution and Nature of the Vegetation of the Sunbury Soil Series. 1961.

The object of the study was to make as complete an investigation of the vegetation of the Sunbury soil series as possible. The intensive nature of the study and the limited amount of time available made it impossible to include all the forest types of the Sunbury series. The study was confined to the University of New Brunswick Woodlot.

Two catenas of the Sunbury series were studied in this area. Using the new soils map produced by the Soil Survey, fifty sample plots were laid out on the Sunbury series of Block 6. Measurements were taken with the object of finding:

1. The variation of the Sunbury soil series itself.

2. The nature of the forest cover.

3. The relation of the tree cover and the ground flora.

4. The interrelation of the different species of the ground flora.

These measurements revealed several facts about the Sunbury soil series and its forest cover. The investigation also showed that, due to the varied microtopography in most Sunbury areas, which resulted in many different ecological niches within each plant community, and due to the ecologically unexacting nature of many of the plants of the ground flora, definite correlations between the ground flora and the forest cover were neither very clear nor very numerous.

With the aid of the sample plot data, interspecific correlation coefficients were calculated between pairs of plants. Only the more numerous and more ecologically important plants were considered. These correlation coefficients expressed the similarity or dissimilarity of the ecological demands of particular plant pairs. From this information a three-dimensional drawing was made which expressed the interrelationships of these plants.

From all this information conclusions were made regarding the distribution of the major plants of the ground flora on the Sunbury soil series, and the use of interspecific correlation coefficients in studying woodland communities.

Macpherson, A. F. Testing the Efficiency of Photo-stratification by Volumeclass, Maturity-group, Cover-type and Drain-class, as used in the 1951-58 Forest Inventory of New Brunswick. 1961.

The double sampling method used in the inventory is described, and the methods used to analyse the data are discussed. These were: (a) comparisons of the accuracy obtained in the inventory with that obtainable by simple 
random sampling and various methods of stratification other than those used; (b) regression analyses of actual on estimated volume for each interpreter in each forest district, measuring consistency at volume interpretation; (c) variance analysis for each interpreter in two districts to test interpreters' ability, by each method of stratification, to divide the forest into strata with different mean volumes; and (d) a chi-square assessment of the correctness achieved with each kind of stratification.

Major conclusions were as follows:

(1) An "optimum" allocation of ground plots to strata (based on the expected within-stratum variance of softwood sawlog volume and on stratum weight in the population), rather than the proportional allocation used, can give considerably increased accuracy of estimate for the more important softwood volume categories; indications were strong that the decrease in accuracy for less important volume categories would be slight.

(2) The effect in reducing standard errors, by stratification by maturity group over and above that by volume class and cover type, was slight, especially in the last districts to be interpreted.

(3) Comparison of the consistency achieved in volume interpretation in New Brunswick using the stereogram-comparison method with that attained elsewhere using aerial volume tables, indicated that at its best the stereogram method is as good as the other, but that otherwise it is less effective. It was concluded that deriving aerial volume tables-which can be done using the inventory results and photo-measurements of the interpreted stands-could result, in future surveys, in raising volume class interpretation to a consistently high level, equal to the best attained using stereograms. Also suggested is a similar approach for improving the consistency of maturity group stratification.

(4) If the variation in ability of each interpreter can be much reduced by using such tables, further gains in accuracy should be achieved in future surveys by using one interpreter only per district. Using stereograms however, pooling the work of several interpreters safeguards against the occasional individual lapses which occurred with this method.

(5) Using the stereogram-comparison method, it is important that interpretation be done in as short a period possible without rushing. The more breaks in the work, the lower is its consistency and the less is its effectiveness.

(6) The interpreters' order of ability tends to be the same at volume, group, covertype and drain stratification. The interpreters are ranked by ability; the rankings differ in each district, but on the average one interpreter seemed superior to the other two.

(7) The correctness of interpretation using stereograms was poor. This does not affect the value of the stratification in increasing the accuracy of the estimates from double sampling, but it impairs seriously the reliability of data, based on photo-interpretation alone, showing the breakdown of the forest by area or volume into forest types.

Powell, G. R. Plant Succession after Forest Fire on Soils of the Sunbury Series. 1961.

The object of this study was to determine the nature of the vegetational succession from initial post-fire conditions to climax forest conditions, on soils of the Sunbury series. 
Burnt-over areas on Sunbury soil were examined and detailed sampling of the vegetation and soil of twenty different burn conditions was carried out.

The initial post-burn vegetations were found to be dominated by species present before the fires. Most of these species had sprouted from unharmed, underground vegetative parts. The initially-established tree species were many, but on a basis of their nature, whether leaf-trees or conifers, intolerant, moderately tolerant or tolerant, they were grouped into four stand types. These stand types were the starting points of four courses of succession towards a common end-the forest type considered to be climax for the areas studied.

Successions of the ground vegetation species accompanied those of the tree species, being largely influenced by the tree cover. As the successions proceeded, there were increases in the depths of the organic soil layers.

A consideration of the burn conditions examined showed the existence of four major vegetation succession trends, after fire, on soils of the Sunbury series.

For your convenience The Forestry Chronicle offers a free employment service. Prospective employers or applicants should write to Mr. George A. Sinclair, Ontario Department of Lands \& Forests, Tweed, Ontario, who will prepare applications for publication. Applicants are requested to include their own advertisement giving the following Information: University granting degree, year of graduation, years and type of experience and type of employment preferred.

\section{Employment Wanted}

Graduate Forester (Master of Forestry Copenhagen 1948), British Columbia Registered Forester, 1958, age 40, married, two children, experienced in forest inventory, logging engineering, silviculture, management desires position with good future where one or several of these experiences may be utilized. Please refer to Code F.M.7.

B.C. Registered Forester, B.S.F., University of British Columbia, 1952. Age 38, married. Experience: Ten years wide forestry experience from temperate forests of Canada to tropical and sub-tropical forests of Southeast Asia; from pulpwood operations in Ontario and Alberta, to heavy logging in Pacific Northwest. Eight years experience with Canadian international consulting firm, two years experience with private pulp firms in extraction and silvicultural work. Experience includes forest inventories, management plans, forestry work connected with hydro-electric developments, silviculture and reforestation. Desires permanent position starting April, 1962. Reply F.M. 10.

Forester B.S.F. (U.B.C.), M.Sc.(Econ.) and Business Administration (London School of Economics), 27, married. Experience in forest management and consulting in B.C. Desires position in forest operations in industry, or where economics training could be utilized. Please refer to code P.E.1.

\section{Mensurationists wanted}

The Forest Research Branch, Dept. of Forestry, Ottawa, requires four forest mensurationists to form a new Forest Mensuration Section. Supervisor's salary $\$ 10,400-\$ 11,800$, others $\$ 5940-\$ 10,300$ depending on qualifications. Competition closes April 30, 1962. See Civil Service Commission of Canada Information Circular No. 62-1455. 